\title{
DRINKING SONGS AMONG THE ANNANG PEOPLE OF AKWA IBOM STATE, NIGERIA
}

\author{
Friday Akpan Okon, \\ Shedrack Monday Johnny ${ }^{\mathrm{i}}$ \\ Department of English, \\ University of Uyo, Uyo, \\ Nigeria
}

\begin{abstract}
:
This paper sets out to examine drinking songs among the Annang people of Akwa Ibom State, in order to show their meaning, general aesthetics and the conditions that necessitated the composition of some of the songs. In order to carry out this objective, the researcher with the help of an assistant, went to some villages in Etim Ekpo Local Government Area and recorded several drinking songs. The analysis of eleven of these songs using Ethnopoetics as the theoretical approach, is what forms the fulcrum of this paper. The result of the findings of this paper are generalized to cover the entire Annang nation, since the culture is homogeneous. Justification for the use of ten drinking songs is that each of the songs portrays a different and unique situation that cannot be substituted for any other. The findings of this paper are that firstly, Annang drinking songs lift the mood of heaviness of the drinkers and makes them jovial. Secondly, the songs create humour, are educative, and are not only interesting and full of aesthetics, but that they are drawn from the people's ancient oral heritage. Equally, the research shows that the Annang adult males captured in these songs are responsible men, who would not hesitate to caution an irresponsible young drinker to mend his ways. The researcher concludes by recommending that these songs should be collected, collated and preserved as being an aspect of the authentic index of the people's cultural heritage.
\end{abstract}

Keywords: Annang, drinking songs, ethnopoetics, oral, palm wine, performance

\section{Introduction}

The study and appreciation of oral literature is more important than ever for understanding the complexity of the human condition. It is observed that among many peoples around the world, particularly in areas where history and traditions are still conveyed more through speech than writing, the transmission of oral literature from one generation to the next lies at the heart of culture and memory. Very often, local languages act as vehicles for the transmission of unique forms of cultural knowledge. Oral traditions that are encoded in these speech forms can become

' Correspondence: email fridayokon@uniuyo.edu.ng, johnnyshedrack@gmail.com 
threatened when elders die or when livelihoods are disrupted (Martindale et al, 2018). The World Affairs Council of Houston puts it this way:

"Oral traditions are messages that are transmitted orally from one generation to another. The messages may be passed down through speech or song and may take the form of folktales and fables, epic histories and narrations, proverbs or sayings, and songs. Oral Traditions make it possible for a society to pass knowledge across generations without writing. They help people make sense of the world and are used to teach children and adults about important aspects of their culture..." (Wikipedia).

Songs occupy an important place in African oral literature and are present in all moments of life, especially on occasions of ritual ceremonies, praises, drinking, war, hunting and other important aspects of life and living. This research gains its background from the Annang cultural practices, and the importance and significance of songs to, and by the Annang people. It focuses mainly on drinking songs (Ikwo Ukıd) and the aesthetics that are embedded in most of these songs, what they mean, and what they symbolize to the people.

\subsection{A Brief History of the Annang People}

The Annang people trace their origin to Bantu-speaking, Zulu hunters in Central Africa. According to Joseph Udondata (2011: v), the migration started in the First and Second Centuries $\mathrm{BC}$ when some Bantu warriors and Zulu hunters left the Central African area via the Congo Basin into the Cameroons region in the $3^{\text {rd }}$ century BC and crossed over to settle at Eket. This narration has been confirmed by Essien Udoh (1983:8) who records that "The Annang first settled at Eket for many years before the visit of the early navigators in 450 BC and the visit of the King of Egypt-(Pharaoh Necho) in 600 BC".

Udondata (2011) and Udondata and Ekanem (2013) further affirm that many ethnic nationalities had established their presence in the Niger Delta region by the $7^{\text {th }}$ Century BC. Among such groups were the Annang, Ibibio, Ijaw, Jekri, Efik and Tiv". Adekunle Ojealabi (1971:74) particularly identifies the Ibibio, Annang, Eket and the Andoni Ibeno as the "aborigines" of the Niger Delta region. The Annang wielded much influence in Ibomland as warriors and priests of their kingdom. They were known as the Oku Ibom Atai of Ibomland and were imbued with the gift of sorcery and divination as well as being the custodians of the Ibinokpabi (Ibritam) shrine (Ukpong David et al, 2001:129).

Today Annang nation comprises eight Local Government Areas in Akwa Ibom State of Nigeria. These are: Abak, Ikot Ekpene, Essien Udim, Ika, Obot Akara, Etim Ekpo, Oruk Anam and Ukanafun. They speak mainly Annang Language with minor dialectal differences in Ukanafun and Ikot Ekpene (Udondata, 2006). The Annang people are about two million in number (2006 population census); and are unique in cultural and traditional practices. Using proverbs is highly desirable, especially among the elders. The American anthropologist, Peter Farb, stated that the name "Annang" among this group means "them who speak well" (https://www.pulse.ng/lifestyle/food-travel-arts-culture/). The Annang is said to be an 
individual who has the gift of eloquent speech, and is often complimented as Akwo Annang, meaning the "singer of Annang" (Udondata, 2011).

It is observed among the Annang that orality has been an important method of selfunderstanding, creative relationships and a means of establishing equilibrium between body, soul and environment. Through oral narrations, most Annang communities have been able to pass down their values, attitudes, knowledge and mode of practices to up-and-coming generations for centuries (Udondata, 2011).

\subsection{Theoretical Framework - Ethnopoetics}

Due to the unpredictable and ephemeral nature of oral literature, it is observed that the performer freely decides what to perform and how to perform it. This leaves the literary analyst in a state of contemplation as to what theory to apply while appraising any oral rendition or performance. Joseph Muleka (2014:147) argues that the choice of theory in oral literature puts the oral artist at the centre, owing to the centrality of the performer in an African oral performance. He further criticizes the unchecked application of the Western type theories to African oral literature as some are not designed to cater for the oral nature of the said literature.

Ethnopoetics is a method of recording text versions of oral poetry or narrative performances (i.e. verbal lore) that uses poetic lines, verses, and stanzas (instead of prose paragraphs) to capture the formal, poetic performance elements which would otherwise be lost in the written text (Wikipedia). The term "Ethnopoetics" was coined in 1968 by Jerome Rothenberg, whose anthology Technicians of the Sacred is seen as a definitive text of the movement. In poetry, Ethnopoetics refers to non-western, non-canonical poetries, often those coming from ancient and autochthonous cultures. In the early $20^{\text {th }}$ century, Modernist and Avant-garde poets such as Antonin Artaud and Tristan Tzara used "primitive" or oral traditions in their works. By midcentury, a curiosity regarding world literature had coalesced into a movement led by Rothenberg and Dennis Tedlock, who together edited the journal Alcheringa from 1970 to 1980 (Robert Moore 2013:30). This partnership gave ethnopoetics its grounding as a critical approach which could be used in recording, transcribing, translating, and interpreting non-western poetry, a category which includes Annang drinking songs.

\subsection{Drinking Songs: A Review}

Drinking songs form a corpus of their own in African oral literature. Unfortunately, they have not received much research attention from both African and Western scholars of oral literature. Ruth Finnegan hardly gives it a mention in her seminal book, Oral Literature in Africa (2012).

A drinking song is a song sung while drinking some alcoholic beverage. Most drinking songs are folk songs, in many cases, composed at the spur of the moment and may be varied from person to person and region to region, in both the lyrics and in the music (Wikipedia https://en.wikipedia.org/wiki/Drinking song). From the above definition, it is observed that the songs are different just as the culture of the drinkers are different. The meaning of these songs may not be generalized since they are deemed to solve various problems with respect to the singers' immediate environment. Friday Okon (2011:110) asserts that "among the Ibibio, drinking songs are sung during drinking sessions by men and young adult males". He observes carefully and 
adds that "such drinking sessions usually take place in the evenings, at the end of the day's work. The location of the event may be a local beer parlour, a chief's compound or a palm-wine-seller's or tapper's shed". Annang drinking songs share these same attributes with drinking songs among their neighbours, the Ibibio. However, there are slight differences.

To add to this body of scholarship, drinking songs among the Annang are not just sung for fun; almost every song signifies and sends a message across to its listeners. Annang drinking songs tend to educate as well as entertain. The messages that are sent across through these songs are not only meant for men; in some cases, women take an active part in chorusing the refrain, to spice up the songs. Annang drinking songs are sung to accompany the drinkers in their drinking session. During the singing and camaraderie, tired workers feel a sense of relief while hungry men forget their pangs of hunger. Drinkers among the Annang spice the drinking session and recapitulate the imagery and taste of the sweetest palm-wine the drinkers have ever drunk in their lifetime. The location in which the drinking songs are sung is not limited to a "local beer parlour, a chief's compound or a palm-wine seller's or tapper's shed", (as observed by Okon, 2011). The songs may also be presented at the night vigil of a loved one or fellow drinker, or at his burial or the burial ceremony of a drinker's relation.

Drinking songs among the Annang can be presented during the celebration of a new born baby in the family of a drinker, the laying of building foundation by a fellow drinker, or any other occasion where free alcoholic beverages are served in large quantities. Annang drinkers enjoy the beauty of life and euphemistically present most serious matters like the death of a king or a priest and any other abominable act in humorous terms, including personal challenges and tragedies.

As observed by Okon (2011), many Ibibio drinking songs are parodies; a corruption of Christian worship songs. Okon confirms that "the original versions of the songs are considered sacred, but their imitations or parodies are corruptions of the former, meant to create humour". He adds that "the parodies tend to reduce the originals to profane levels, in order to cause laughter and ridicule" (2011:111). However, the Annang drinking songs that are presented in this research are not parodies of any original songs as seen in Okon (2011:112-117); this is what marks the uniqueness of the research. The songs themselves are of communal ownership, traced to the oral traditions of the Annang people. The inspiration for the songs is the daily events and circumstances that triggered Annang drinkers in the past to compose the songs, which were later transmitted from one generation to another by word of mouth.

\subsection{Aesthetics}

Aesthetics in this context subsumes the ability to recognize or apprehend and appreciate beauty. It is the deployment of all the resources of language and form to make a conceptualized idea perceptible to an audience (Angmor 1993:112), whether in an oral or written form. Aesthetics is a state of mind shared by a community as to what the standard for beauty is and what is not. This shared communal mindset evokes communal harmony, unity and the continual observances of traditions, customs and values which aesthetic delight generates. Aesthetics, therefore, to a large extent, is a cultural product, and it varies from culture to culture. Therefore, 
the aesthetics embedded in Annang drinking songs may not be shared by other groups, and viceversa.

\section{Annang Drinking Songs, their Aesthetics and Interpretation}

Due to the creative ability of the Annang drinkers, songs are composed with regards to instances and occasions that surround the songs. For this reason, like their counterpart among the Ibibio, many of the songs are actually impromptu or on the spur of the moment, according to the volume of the flow of the drink. The more drinks are donated (which gesture is received with loud applause and acclamation), the merrier the singing and the sharper the inspiration. The songs send a clear message to their listeners and even to those that may not have witnessed certain antecedent activities of the group.

Improvisation is the order of the day in these songs because they are accompanied with improvised musical instrumentation like beating of bottles or plates and clapping of hands to give melody and rhythm for the free flow of the song. The aesthetic value of the songs that are presented below are manifested in the memory of those who sing the songs very well or those that have had deep experience in watching Annang artists present similar songs at different occasions. The uniqueness of these songs is that they are all original versions of songs and not a substitution of any other religious, traditional or cultural songs. The manifestation of their natural rhythm lies in the ability of the audience to experience the performers performing the songs in their original state. This paper shall present various Annang drinking songs and their aesthetics of presentation and interpretation as seen below.

\subsection{Song 1}

\section{Original}

Úköd nsöng

Ádè àtá ékámbá úköd

Úköd nsöng

Ádè àtá éti ùköd O!

Àmá ñwöng ànyé $\mathrm{O}$ !

Àfò àná kút ùfön ömö $O$ !

\section{Translation}

Palm wine

Is a very important drink

Palm wine

Is a very good drink $\mathrm{O}$ !

When you drink it $\mathrm{O}$ !

You'd experience its benefits $\mathrm{O}$ !

Among the Annang drinkers, the above song is used to open any drinking session. The drinkers sing this song in order to add value and also praise palm wine as a very useful drink. On several occasions, the 'Ákwâ Ikwö Ùköd' (cantor) will recount the benefits of palm wine in the background of the song while other singers chant only the verses above, as refrain.

A prominent aesthetic consideration in the song is the use of interjection, as in lines 4-6:

Ádè àtá éti ùköd $\mathrm{O}$ !

Àmá ñwöng ànyé $\mathrm{O!}$

Àfò àná kút ùfön ömö $\mathrm{O}$ !
Is a very good drink $\mathrm{O}$ !

When you drink it $\mathrm{O}$ !

You'd experience its benefits $\mathrm{O}$ 
The interjection is deployed above when the singer is making what he considers an incontrovertible statement; in other words, a declarative statement. Such statements are usually not open to debate (Eka 2017:49). In the above song therefore, the cantor of the song feels that he is speaking on the authority of experience of the benefits of palm wine to the drinker.

\subsection{Song 2}

\author{
Original \\ Cantor: Nsidé imá? \\ Chorus: Imá ádè ilibònò ntö kiet $\mathrm{O}$ ! \\ Cantor: Nsidé imá? \\ Chorus: Imá ádè ilitök'ùköt iñwöng
}

\section{Translation}

Cantor: What is love?

Chorus: Love is staying together in one accord

Cantor: What is love?

Chorus: Love is gathering to drink palm wine.

Among the Annang drinkers, the above song is usually chanted in a 'call and response manner'. The person who takes the lead (cantor) chants (Nsidé imá? What is Love?) with all amount of joy expecting the quick response of (Imá ádè ilibònò ntö kiet $\mathrm{O}$ !) from his co-drinkers. The rendition continues in this manner to the final lines of the song. The Annang drinkers use this particular song to re-emphasize the meaning of love among themselves, singing the song aloud to the hearing benefit of passers-by who they think do not love themselves enough, compared to the love they (the drinkers) have for each other, by sharing their palm wine among themselves.

The main idea in the song which the drinkers are intent on passing to the audience is simply that 'there is love in sharing'. Part of the aesthetic value of this song is embedded in the ability of these drinkers to express their feelings through the song and in preaching the sermon of love to the people. Although drinkers are referred to, and regarded as unserious people, their expressions of love in the above song depicts some element of wisdom higher than what any non-drinker might imagine.

In terms of other noticeable aesthetic devices, the drinkers make use of the rhetorical question device and repetition as in lines 1 and 4: Nsidé ima? (What is love?). The rhetorical question only presents a well-known issue that requires no response, while the repetition is for emphasis. The repetition of the question is to lay emphasis on the fact that love is an indispensable fact of life, even more so among drinkers, who must continually share their liquor with all and sundry.

\subsection{Song 3 .}

\section{Original}

Bén àsàkpá li

Ké iná iñwöng

Ùtú ké itié ntélè

Iná iñwöng

Ùtú ké itié ntélè

\section{Translation}

Bring many-days-old palm wine

We will drink

Instead of sitting empty

We will drink

Instead of sitting empty 


\section{Iná iñwöng \\ Ùtú ké itié ntélè \\ Iná iñwöng}

\author{
We will drink \\ Instead of sitting empty \\ We will drink
}

Drinking is a major item in several Annang traditional gatherings. Among the Annang people, 'àsàkpá' as used in the above song is what could be referred to as many-days-old palm wine, which has a very strong sour taste. The song is often sung on several occasions when the drinkers gather but are denied the privilege of drinking, maybe because the palm wine tapper has not returned for that session (morning or evening), or else, there happens to be no fresh wine for them at that moment. The song is chanted by a cantor who takes the lead and is followed by a chorus of his fellow drinkers who repeatedly yearn for even many-days-old and left-over wine in order to spice up their gathering. The above song adds colour to any gathering, and makes the place lively even when there is no palm wine, till the drinkers dismiss.

The most outstanding stylistic device used in this song is repetition. The repetition emphasizes the fact of the drinkers' desire to drink something. Such repetition is found in lines 2,4,6 and 8:
Ké iná iñwöng
We will drink.

With this repetition, the organizers of the event have no choice than to pacify the drinkers with some palm wine.

\subsection{Song 4}

\section{Original}

Tökö úköd nnö nyien

Tökö dé ñwöng

Mkpöng áñké ñwöngö

Áké ánám sé?

\section{Translation}

Give me some palm wine

And drink some yourself

Yesterday when I drank

What did it do to me?

During most drinking sessions, the palm wine is first shared to everybody using the drinking gourd. The above song is usually sung by the one person who provides the palm wine. He advises the one who shares the drink to everybody not to entertain any fears about wine, telling him that he (the donor) drank the wine a day before the meeting day, and it did no harm to him. This advice is meant to allay the fears of any newcomer to the group who may feel a sense of queasiness about the wine. In the same vein, tradition and custom among the Annang and Ibibio presupposes that the donor of any alcoholic beverage must of necessity be the first to taste the drink in order to dispel any fears that he may have laced the drink with dangerous substances. The above song underscores this fact. 


\subsection{Song 5}

\section{Original}

Àmi ñwöngö ñwöng

Ùbòn été éwó

Àmi ñwöng ñkànà

Ñwöngö ñwöng o!

Ùbòn été éwó

Ké ndè àñwöng kpá

\section{Translation}

I have not yet drunk

My father's family says

I drink the most

I have not even drunk o!

My father's family says

I am a drunkard

The choice of words and the aesthetic value of the above song is very captivating to the mind; its interpretation gives a broader meaning compared to what a drinker could sing. The song persona being a habitual drinker, makes an effort to convince non-drinkers that the extent is not too much. He does this by exaggerating the displeasure of his father's kinsmen to his drinking habit, thus:
Ñwöngö ñwöng o!
I have not yet drunk o!
Ùbòn été éwó
(But) my father's family says
Ké ndè àñwöng kpá
I am a drunkard

By emphasizing and exaggerating this accusation, he is seeking sympathy, and at the same time, trying to prove that his drinking is only moderate. In order to pass this information to the ears of his people in a peaceful way, he composes the above song and makes use of it at various gatherings of drinkers. Another aesthetic device noticed here is the use of repetition. Here it serves the dual function of emphasizing the drinker's defense, as well as acting as an enhancer of the rhythm and melody of the song.

\subsection{Song 6}

\section{Original}

Ùfàn-èté li ñwöng nn'èmi

Li ñwong nn'èmi

Ùfàn-èté li ñwöng nn'èmi

Àfò àmá ñwöng nn'èmi

Úköd ámi áná fön ne'jid

\section{Translation}

Father's friend come and drink with me

Come and drink with me

Father's friend come and drink with me

If you drink with me

This palm wine will be good with us.

The above song emphasizes the need for an elderly person to accompany younger drinkers during drinking sessions, as seen above, the young drinker in the absence of the father (who is believed to also be a drinker) calls on his father's friend to drink with him in the belief that if they drink together, the palm wine will be good with them both.

The main stylistic device used in this song is repetition which occurs in lines $1-4$. Line 1 is repeated in line 3: 
Ùfàn-èté li ñwöng nn'èmi Ùfàn-èté li ñwöng nn'èmi
Father's friend come and drink with me (Line 1)

Father's friend come and drink with me (line 3)

Equally, line 2 is repeated in line 4, except that there is a slight adjustment in the use of a conditional pronoun, thus:
Li ñwong nn'èmi
Come and drink with me (line 2)
Àfò àmá ñwöng nn'èmi
If you drink with me (line 4)

This repetition serves to lay emphasis on the idea of friendship, company and sharing. However, it also enhances the rhythm of the song.

\subsection{Song 7}

\section{Original}

Mbónó ámi iwi inâ àbà

Ké àmá ùliökö úköd ké àkpókóró If you don't place wine on the table

Mbónó ámi iwi inâ iwùò

Ké ili ñwöngö úköd k'imá

\section{Translation}

This gathering will no longer hold

This gathering will not make a headway

If we don't drink wine with love

The song is employed in a situation where a number of persons have gathered for a meeting, and perhaps they have started and there is no drink before them on the table. Since drink (palm wine) is a major and interesting part of the meeting, the drinkers protest through the above song to express their sadness, commenting that the meeting will not make any headway if there is no palm wine on their table. By doing so, whoever convened the meeting will now be expected to make necessary arrangements that will satisfy the drinkers' wishes. Overall, the drinkers in this event stress the bond of love that binds drinkers together. Repetition is also noted in the entire song. Line 1 repeats in line 3 while line 2 repeats in line 4 . However, in each repetition, slight changes that both foreground the idea as well as move it forward is observed. This is known as incremental repetition, thus:
Mbónó ámi iwi inâ àbà This gathering will no longer hold (Line1)
Mbónó ámi iwi inâ iwùò This gathering will not make a headway (line3)

Similarly, we have the following in lines 2 and 4:

Ké àmá ùliökö úköd ké àkpókóró

Ké ili ñwöngö úköd k'imá
If you don't place wine on the table (Line 2) If we don't drink wine with love (Line 4) 


\subsection{Song 8}

\section{Original}

Imibàn idök mwiré úköd

Iminyimé ké idè mmè àñwöng úköd

Èté, kú nkód

Ké ndè àñwöng ñköd o!

Èkà, kú ñkód

Ké mbâ ké itié úköd

Mményimé ké ndè ùfàn úköd

Mmá bàn ndök úfök úköd.

\section{Translation}

We have initiated into the palm wine play

We agree we are wine bibbers

Father, do not call me

For I am a drinker o!

Mother, do not call me

For I am in the drinking joint

I agree I am a friend to palm wine

I was initiated to the house of palm wine.

This song is often sung in a drinking joint, or at the home of a deceased wine bibber, on the eve of his funeral. The Annang drinkers also sing this song at various other celebrations or festivals where they will obviously separate themselves from others, to eat and drink on the basis of initiation. This is to say that one who is not acclaimed as a drinker and is not known among them as an initiate is not allowed to take part in their exclusive gathering. Every drinker has to sing this song to tell the world the joy found in the group he belongs to and make a boast of the group by advising his parents not to call or look for him being that he is a friend to palm wine and was initiated into the wine play.

\subsection{Song 9}

Úköd nsöng ányé ádé ibök Úföföp ányé ádé òbùmà; Àñwöng úköd nsöng Inyénéké ùtò-ényèn k’idèm!
Palm wine is a medicine Local gin (Ufofop) is thunder; A palm wine bibber Does not suffer from malaria!

This song reiterates the boast that palm wine drinkers often make in the presence of nondrinkers that those who drink hardly suffer from the effects of malaria. Malaria is the bane of the tropics, and tropical Africa which includes Nigeria, is one of the worst hit, as a result of the presence of mosquitoes. The song says that palm wine is a(n anti-malarial) drug, while homemade gin is the thunder that shatters the pains of illness to release the drinker from the pangs of ill-health. The song concludes by saying that palm wine bibbers do not suffer from malaria. The main stylistic/aesthetic device used in this song is metaphor, where palm wine is said to be medicine and local gin, thunder:
Úköd nsöng ányé ádé ibök
Palm wine is a medicine
Úföföp ányé ádé òbùmà
Local gin (Ufofop) is thunder

By this device, the drinkers flaunt their prowess before non-drinkers as a way of making their way of life alluring to the latter to persuade them to join the drinkers' club. 


\subsection{Song 10}

$\begin{array}{ll}\text { Tökö ñwöng! } & \text { Pour and Drink! } \\ \text { Tökö ñwöng! } & \text { Pour and Drink! } \\ \text { Ké mmè àñwöng mkpö-àgwò } & \text { For all wine-bibbers } \\ \text { Ényéné idiöngö! } & \text { Have their special mark! }\end{array}$

The song is a further boast by drinkers directed at non-drinkers. In the song, an initiate is encouraged to pour the wine and to drink it because wine-bibbers have their peculiar mark of identification and fellowship. In a sense, it appears as if this mark of identification makes it possible for bibbers to recognize each other even in distant places where they may be strangers to each other. For this reason, it is assumed that drinkers can never be stranded wherever they find themselves, because they stand to be assisted, hosted and shown love and hospitality by their fellows wherever they meet. The main stylistic/aesthetic device used in this song is repetition, where the neophyte is encouraged to pour the wine and drink to seal the mark of fellowship:
Tökö ñwöng!
Pour and Drink!
Tökö ñwöng!
Pour and Drink!

Repetition plays a vital role in African oral songs (Okpewho 71). Structurally, they aid in lengthening the song and in terms of musicality, they enhance the rhythm of the song.

However, the impression created is not that these Annang drinkers are irresponsible members of the society. Rather, the researchers wish to convey the idea that drinking is an avenue for creativity and the use of the imagination for the relaxation and pleasure of not only the drinkers, but also the passers-by who listen to their songs. In other words, drinking songs has also been used as an instrument of censure, as in the example below:

\subsection{Song 11}

Ñwöng nnö ikó

Ké ùsö ikiñwöngö ntôm

Ikidö ùkà!
Drink and return the gourd to me

For your father did not drink like this

And married your mother!

This advice is usually given to younger drinkers who abandon their responsibilities and engage in drinking for drinking sake. Such are regarded as unproductive persons who contribute nothing positive to their own wellbeing or even to their communities, and therefore, must be censured. The young drinker is indirectly told to be productive so that he can fulfill communal expectations of marrying and maintaining a family. This is done by referring to the achievements of his father who fulfilled his obligations to the community by marriage and by begetting him, the drinker: 
Ké ùsö ikiñwöngö ntôm

Ikidö ùkà!
For your father did not drink like this

And married your mother!

On the contrary, drinking is regarded as a pastime to be engaged in after the day's work has been done or during communal celebrations like festivals, child-naming or dedication, coronation, funeral, and so on. During such occasions, the drinkers are given a separate table to sit and enjoy themselves; at the same time, by their presence, they help to enliven the occasion with their humorous songs and displays.

\section{Conclusion}

From time immemorial, man has always sought for ways and means of entertaining himself and his fellows, orally (Onuekwusi, 2001). One of such effective ways has been through the avenue of drinking songs. This research set out to examine selected Annang drinking songs showing their meaning, general aesthetics and the conditions that necessitated the composition of some of the songs. Drinking songs among the Annang can be traced to the oral traditions of the people in the past. The process of drinking creates an avenue for relaxation, education of the mind and the entertaining of oneself. It is an avenue where some men take their domestic problems to, for solution, advice and suggestions by others who must have faced similar problems. This is grounded on the belief touted by the Ibibio and Annang in their proverb that: "Ágwó ábènnè nkányá ákâ àfé àwô yàk ékénè ènyé ékûm" (he who takes his mat to the village assembly-hall is inviting people to help him sew it). Those who quarrel usually settle their differences over a gourd of palm wine, and therefore, the drinking serves as an avenue for the settlement of some public issues, thereby promoting and maintaining public order, peace and harmony in society. The researchers have noticed that drinking songs can be used to criticize, censure and correct any negative behaviour that threatens to mar that societal harmony. This research acknowledges the aesthetic qualities embedded in the songs and avers that the interpretation of the songs is in consonance with the cultural traditions of the people, in this case, the Annang. This paper concludes that these songs should be collected, collated and preserved as an index of the people's authentic cultural heritage.

\section{Conflict of Interest Statement}

The authors declare no conflicts of interests.

\section{About the Authors}

Friday A. Okon (PhD), is an Associate Professor in the Department of English, University of Uyo, Uyo, Nigeria. His research interests include European Literature, African Oral and Written Literatures.

Shedrack M. Johnny is an undergraduate Student of the Department of English, University of Uyo, Uyo, Nigeria. He has a deep interest in Oral Literary Research. 


\section{References}

Angmor, C. (1993). “Two Decades of Contemporary Nigerian Novel”. Journal of Humanities, Vol. III, September, University of Uyo: 111-123.

Drinking Songs and Features. Wikipedia free encyclopedia; https://en.wikipedia.org/wiki/Drinking_song, Retrieved 31st October 2018.

Eka, D. (2017). Elements of Grammar and Mechanics of the English Language. Uyo: Samuf.

Farb P. (2018). What You Didn't Know About the Annang People; https://www.pulse.ng/lifestyle/food-travel-arts-culture/what-you-probably-didntknowabout-the-anaang-people-id7469159.html, Retrieved 5th Oct. 2018.

Finnegan, R. (2012). Oral Literature in Africa. Cambridge: Open Book Publishers https://doi.org/10.11647/OBP.0025

Hymes, D. (1986) In Vain I Tried to Tell You: Essays in Native American Ethnopoetics. Philadelphia: University of Pennsylvania Press.

Martindale, A., Schneiderman, S., and Mark T. "Time, Oral Tradition and Technology". Memory (Eds., Philippe Tortell, Mark Turin and Margaret Young). Peter Wall Institute for Advanced Studies, 2018. https://doi.org/10.2307/ij.ctvbtzpfm. (197-206)

Moore, R. (2013). Reinventing Ethnopoetics. Indiana: Indiana University Press (2013).

Muleka, J. (2014). "Theory in the Study of African Oral Literature: The Oral Artist's Agenda" Journal of Arts and Humanities Vol 3, NO 7, 2014. 145-160.

Ojealabi, A. (1971). A. A Textbook of West African History. Ibadan: Educational Research Institute.

Okon, F. (2011). "Parody as Aesthetics in Ibibio Drinking Songs" in Ife Studies in African Literature and the Arts (ISALA), $109-121$.

Okpewho, I. (2004). African Oral Literature: Background, Character and Continuity. Bloomington, Indiana: Indiana University Press.

Onuekwusi, J. (2001). Fundamentals of African Oral Literature. Owerri: Alphabet, 2001.

Oral Tradition of West Africa and Literature. World Affairs Council (2018). https://static1.sguarespace.comlstatic/53cfdOe5e4bO57663ea1bc61/t/57b1t0b746c3c4O6d d172afd/1471275383444/Oral+Traditions+of+West+Africa.pdf Retrieved 5th Oct. 2018.

Udoh, E. U. (1983). The History of the Annang People. Calabar, Nigeria: Apcon Press Ltd.

Udondata, J. P. (2006). A Grammar of Annang Language. Ikot Ekpene: Joe Graph Publications.

Udondata, J. P. (2011). Annang Traditional Literature. Uyo: Scholars Press.

Udondata, J. and Ekanem, J. B. (2013). The Annang People of Nigeria: History and Culture. Texas: Altrubooks mc.

Ukpong, D., Akpan M., and Akang, N. (2001). The Cradle of Ibibio Nation. Uyo: Dorand Publishers. 
Creative Commons licensing terms

Author(s) will retain the copyright of their published articles agreeing that a Creative Commons Attribution 4.0 International License (CC BY 4.0) terms will be applied to their work. Under the terms of this license, no permission is required from the author(s) or publisher for members of the community to copy, distribute, transmit or adapt the article content, providing a proper, prominent and unambiguous attribution to the authors in a manner that makes clear that the materials are being reused under permission of a Creative Commons License. Views, opinions and conclusions expressed in this research article are views, opinions and conclusions of the author(s). and European Journal of Literature, Language and Linguistics Studies shall not be responsible or answerable for any loss, damage or liability caused in relation to/arising out of conflicts of interest, copyright violations and inappropriate or inaccurate use of any kind content related or integrated into the research work. All the published works are meeting the Open Access Publishing requirements and can be freely accessed, shared, modified, distributed and used in educational, commercial and non-commercial purposes under a Creative Commons Attribution 4.0 International License (CC BY 4.0). 